\title{
A CEBPA-mutációk vizsgálata és prognosztikai jelentőségük akut myeloid leukémiában
}

\author{
Ifj. Nagy Béla1, ${ }^{1,}$, Gángó Ambrus², Rejtő Lászlón ${ }^{3}$ Krizsán Szilvia² ${ }^{2}$ Ujfalusi Anikón , \\ Antal-Szalmás Péter ${ }^{1}$
}

\author{
'Debreceni Egyetem, Általános Orvostudományi Kar, Laboratóriumi Medicina Intézet, Debrecen \\ ${ }^{2}$ Semmelweis Egyetem, MTA-SE Lendület Molekuláris Onkohematológia Kutatócsoport, \\ I. sz. Patológiai és Kísérleti Rákkutató Intézet, Budapest \\ ${ }^{3}$ Szabolcs-Szatmár-Bereg Megyei Kórházak és Jósa András Egyetemi Oktatókórház, \\ Hematológia Osztály, Nyíregyháza
}

\begin{abstract}
A molekuláris genetikai vizsgálatok nagyléptékü fejlődése az elmúlt években lehetôvé tette a malignus myeloid kórképek hátterében álló genetikai eltérések detektálását. Ennek köszönhetően az akut myeloid leukémiában (AML) gyakoribb mutációk egyre teljesebb körű vizsgálata jelentősen javította a kórkép diagnosztikáját, prognosztikai értékelését, valamint a terápiára adott válasz és a relapszus valószínűségének előrejelzését. Az AML patogenezisében fontos szerepet játszanak a különböző transzkripciós faktorok genetikai eltérései, amelyek a hematopoetikus őssejt myeloid irányba történő differenciációját segítik elő. Ezen fehérjék közé tartozik a CEBPA (CCAAT/enhancer binding protein alpha) gén által kódolt, leucincipzár-motívumot tartalmazó transzkripciós faktor is. A CEBPA fehérje a granulocyták differenciációjában vesz részt, míg a mutációja a myeloid blastok kontrollálatlan proliferációját okozhatja. Sporadikus AML-ben a betegek körülbelül 5-10\%-ában mutatható ki a CEBPA gén mutációja, leggyakrabban normál kariotípusú, általában éretlen morfológiájú de novo AML-ben. A CEBPA génnek csíravonalbeli és szomatikus mutációit különböztetjük meg. A familiáris $\mathrm{AML}$ egyik csoportjában („AML with germline $C E B P A$ mutation”) a CEBPA génmutációk autoszomális domináns módon öröklődnek és jelenlétük minden esetben közel $100 \%$-os penetranciával a betegség kialakulásához vezet. Két mutáció jelenléte (biallélikus forma) kedvező klinikai lefolyással társul, ami önálló entitásként szerepel az akut leukémiák 2016-os WHO-klasszifikációjában. Jelen összefoglaló közleményünkben a CEBPA génmutációk laboratóriumi diagnosztikai vizsgálatát és annak klinikai, prognosztikai jelentőségét mutatjuk be.
\end{abstract}

Kulcsszavak: akut myeloid leukémia, $C E B P A$, prognosztika, Sanger-szekvenálás, génmutáció

\section{Laboratory analysis and prognostic values of $C E B P A$ gene mutations in acute myeloid leukemia}

Due to the rapid development of molecular laboratory diagnostics, detection of genetic alterations in the background of malignant myeloid diseases has become available in the last couple of years. Hence, the wider range of analysis of mutations in acute myeloid leukemia (AML) has substantially improved the diagnosis of this disease, the evaluation of prognosis, and the indication of clinical response to therapy with the risk of relapse. In the pathomechanism of AML there are several mutations of key transcriptional factors, which propagate the differentiation of hematopoietic stem cell into myeloid lineage. Among these proteins, CEBPA (CCAAT/enhancer binding protein alpha) is one of these transcriptional factors containing a leucine zipper motif. Normally, CEBPA protein is involved in the differentiation of granulocytes, while its mutated form results in uncontrolled proliferation of myeloid blasts. In sporadic AML, CEBPA gene mutations can be detected in about $5-10 \%$ of cases, usually in undifferentiated de novo AML with normal karyotype. Germline and somatic $C E B P A$ mutations may be generated. In familiar AML, germline CEBPA mutations are inherited in an autosomal dominant pattern and their presence has almost $100 \%$ penetration for the development of disease.

@ Levelezési cím: Dr. Nagy Béla, Debreceni Egyetem, ÁOK, Laboratóriumi Medicina Intézet, 4028 Debrecen, Nagyerdei krt. $98 . ;$ Tel.: 52/340-006; E-mail: nagy.bela@med.unideb.hu 
AML with biallelic CEBPA mutations shows a better prognosis and became a new entity in the 2016 WHO classification of acute leukemias. In this review, we summarize the main aspects of laboratory analysis of $C E B P A$ gene mutations with their clinical and prognostic values.

Keywords: acute myeloid leukemia, $C E B P A$, prognosis, Sanger-sequencing, gene mutation

(Beérkezett: 2018. december 20.; elfogadva: 2019. február 23.)

\section{Rövidítések}

$\mathrm{AML}=$ akut myeloid leukémia; $\mathrm{CEBPA}=\mathrm{CCAAT} /$ enhancer binding protein alpha; $\mathrm{MDS}=$ myelodysplasiás szindróma; $\mathrm{MRD}$ = minimális reziduális betegség; GATA 2 = GATA binding protein 2; RUNX1 = Runt-related transcription factor 1; FLT3 = fmslike tyrosine kinase 3; NPM1 = Nucleophosmin 1; IDH1 és IDH2 = izocitrát-dehidrogenáz 1 és $2 ; \mathrm{PCR}=$ polimeráz láncreakció; WES = teljes exomszekvenálás; OS = teljes túlélés; RFS = relapszusmentes túlélés; FLT3 ${ }^{I T D}=$ FLT3 internal tandem duplication

\section{Az AML genetikai háttere}

Az AML egy meglehetősen heterogén, agresszív lefolyású betegség, melynek hátterében a myeloid sejtek kontrollálatlan proliferációja és differenciációjának zavara áll. Incidenciája évente kb. 2-3/100000 fö, mely az életkorral fokozatosan nő. Döntően de novo alakul ki, viszont az esetek kb. 20-25\%-ban más myeloid betegségek, úgymint myelodysplasiás szindróma (MDS), illetve myeloproliferatív kórképek transzformációja vezethet AML-hez, továbbá terápia indukálta szekunder AML-ként kerülhet diagnosztizálásra [1].

Az AML diagnosztikája citológiai és szövettani, áramlási citometriai, citogenetikai és molekuláris genetikai vizsgálatokon alapszik. A diagnózis alapja a $20 \%$ feletti blastarány a perifériás vér- és/vagy a csontvelői mintában, és elengedhetetlen a betegminta áramlási citometriai analízise a kóros sejtek karakterizálása érdekében [2] Az utóbbi vizsgálatok kiegészülve a molekuláris genetikai analízissel segítséget jelentenek a terápiára adott válasz értékelésében és a minimális reziduális betegség (MRD) megállapításában is.

$\mathrm{Az}$ AML-es esetek kb. 50\%-ban kimutathatók kromoszómaaberrációk. A kromoszómák számbeli eltérésével nem járó esetek (transzlokációk, inverziók) egy része kedvező prognózisú. Ezek közé tartoznak a t(15;17), az inv(16), illetve $\mathrm{t}(16 ; 16)$, valamint a $\mathrm{t}(8 ; 21)$, melyek az összes AML-es esetek kb. 20\%-át jelentik. A kedvező kariotípusú csoportban a betegek ötéves túlélése akár $60-80 \%$ is lehet [3]. A normál kariotípusú AML viszont egy meglehetősen heterogén csoport, amelyben a kezelés eredményessége betegenként eltérő lehet a detektálható génmutációktól függően. A mutációk olyan funkcionális fehérjék génjében (pl. sejtciklus szabályozók, szignál transzdukciós faktorok, DNS-metilációt szabályzó fehérjék stb.) alakulhatnak ki, mely fehérjék megváltozott működése elősegíti az AML kialakulását vagy jelentősen befolyásolja annak prognózisát [4]. Idetartoznak a transzkripciós szabályozásért felelős DNS-kötő fehérjék is, melyek a különböző gének átíródásának szabályozásában vesznek részt. Ezek közé sorolhatók a CEBPA (CCAAT/ enhancer binding protein alpha), a GATA2 (GATA binding protein 2) és a RUNX1 (Runt-related transcription factor 1) gén által kódolt fehérjék, melyek mutációi önmagukban, illetve egyéb mutációkkal társulva eltérő klinikai lefolyást eredményeznek AML-ben [4]. A CEBPA az AML diagnózis felállításakor vizsgálandó leggyakoribb prognosztikai markerek közé tartozik az FLT3 ${ }^{I T D}$ (fms-like tyrosine kinase 3 , „internal tandem duplication”) és a NPM1 (Nucleophosmin 1) mutációkkal együtt [1,2]. Emellett az „European Leukemia NET” 2017-es ajánlása értelmében a RUNX1, ASXL1, TP53 génmutációk vizsgálata is fontos, mivel kedvezőtlen prognózissal társulnak [2]. Az FLT3 ${ }^{T K D}$ (FLT3 gén tirozinkináz domént érintő pontmutációja), valamint az IDH1 és IDH2 (izocitrát-dehidrogenáz 1 és 2) génmutációk ellentmondó eredményeket mutattak $[1,2$, 4]. Ugyanakkor már léteznek olyan célzott terápiák, amelyek miatt fontos lehet a jövőben a vizsgálatuk.

Az AML-ben kimutatható különböző génmutációk jelenléte alapján a betegek három rizikócsoportba sorolhatók: kedvező, intermedier és kedvezőtlen csoportba [2], amit az 1. táblázatban foglaltunk össze. A kedvező csoportba sorolható betegek többek között RUNX1RUNX1T1 génfúziót, mutált NPM1-t FLT3 ${ }^{I T D}$ mutáció hiányában vagy alacsony allélaránnyal $(<0,5)$, illetve biallélikus $C E B P A$-mutációt mutatnak. Az intermedier prognózisú személyek ezzel szemben NPM1 génmutáció mellett magas $F L T 3^{I T D}$ allélaránnyal $(\geq 0,5)$ rendelkeznek, vagy vad típusú $N P M 1$ társul alacsony $F L T 3^{I T D}$ allélaránnyal vagy vad típusú FLT3 génstátusszal. Kedvezőtlen viszont azoknak a betegeknek a prognózisa, akiknek három vagy több független kromoszómarendellenessége van (pl. a 11q23-rendellenességek, del(5q) vagy $-5, \operatorname{del}(7 q)$ vagy -7 , inv(3) vagy t(3;3)). Ezek az összes AML kb. 30\%-ában mutathatók ki. Ebbe a rizikócsoportba tartoznak még a $B C R-A B L 1$-transzlokációt mutató, illetve a vad típusú NPM1-t és magas FLT3 ${ }^{I T D}$ allélarányt mutató betegek is 
1. táblázat. Az AML ELN által javasolt rizikócsoport-beosztása a citogenetikai és molekuláris genetikai eltérések alapján [2]

\begin{tabular}{ll}
\hline Rizikócsoport & Genetikai eltérés \\
\hline Kedvező & $\mathrm{t}(8 ; 21)(\mathrm{q} 22 ; \mathrm{q} 22.1) ;$ RUNX1-RUNX1T1 \\
& inv(16)(p13.1q22) vagy $\mathrm{t}(16 ; 16)(\mathrm{p} 13.1 ; \mathrm{q} 22) ; C B F B-M Y H 11$ \\
& Mutált $N P M 1, F L T 3-I T D$ nélkül vagy alacsony FLT3-ITD allélaránnyal \\
& Biallélikus mutált CEBPA \\
\hline Intermedier & Mutált NPM1 és magas FLT3-ITD allélarány \\
& Vad típusú NPM1 FLT3-ITD nélkül vagy alacsony FLT3-ITD allélaránnyal (kedvezötlen genetikai eltérések nélkül) \\
& $\mathrm{t}(9 ; 11)(\mathrm{p} 21.3 ; \mathrm{q} 23.3) ; M L L T 3-K M T 2 A$ \\
& Egyéb citogenetikai eltérés, mely kedvező vagy kedvezőtlen rizikócsoportba nem sorolható \\
\hline Kedvezőtlen & $\mathrm{t}(6 ; 9)(\mathrm{p} 23 ; \mathrm{q} 34.1) ; D E K-N U P 214$ \\
& $\mathrm{t}(\mathrm{v} ; 11 \mathrm{q} 23.3) ;$ KMT2A-átrendeződés \\
& $\mathrm{t}(9 ; 22)(\mathrm{q} 34.1 ; \mathrm{q} 11.2) ; B C R-A B L 1$ \\
& inv(3)(q21.3q26.2) vagy $\mathrm{t}(3 ; 3)(\mathrm{q} 21.3 ; \mathrm{q} 26.2) ; G A T A 2, M E C O M(E V I 1)$ \\
& -5 vagy del(5q);-7;-17/abn(17p) \\
& Komplex kariotípus, monoszómális kariotípus \\
& Vad típusú $N P M 1$ és magas FLT3-ITD allélarány \\
& Mutált $R U N X 1$ \\
& Mutált $A S X L 1$ \\
& Mutált TP53
\end{tabular}

[2] (1. táblázat). A kedvezőtlen kariotípusú csoportban az ötéves túlélés kevesebb mint $20 \%$ [3].

\section{A CEBPA gén és mutációtípusai}

A CEBPA a 19-es kromoszóma hosszú karjáról expresszálódó, leucincipzár-motívumot tartalmazó 42 kDa-os transzkripciós faktor (p42), amely a neutrophil granulocyták érésében vesz részt. A normál szerkezetú és müködésű CEBPA fehérje a granulocyta differenciációt szabá- lyozza, míg mutációt hordozó rövidebb formája a myeloid blastok szabályozatlan proliferációját okozhatja [5]. A fehérjén belül az úgynevezett $\mathrm{N}$-terminális régióban ( 5 ' szakasz) transzaktivációs domének találhatók (TAD1, TAD2), míg a C-terminális régióban (3' szakasz) a DNSkötésért és a dimerizációért felelős bázikus leucincipzár domén (Basic Leucine Zipper Domain, bZIP) helyezkedik el (1. ábra). Ezek alapján a CEBPA gént érintő genetikai eltérések alapvetôen két csoportba sorolhatók. Az első csoportba tartoznak a csíravonalbeli/öröklődő mutációk,

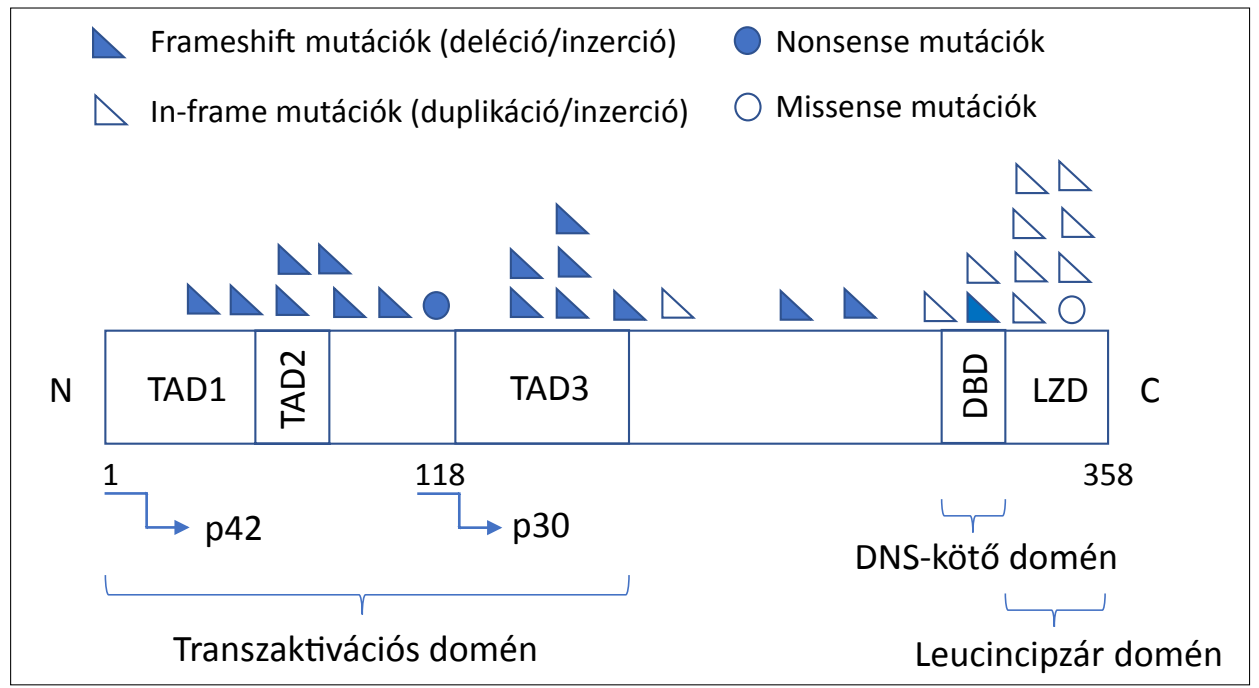

1. ábra. A CEBPA fehérje normál és kóros szerkezete, és génjének az N-, illetve C-terminális régiójában kialakuló különböző típusú mutációk elhelyezkedése. A csíravonalbeli mutációk a TAD1 és TAD2 régióban, míg a szerzett mutációk a DBD és LZD régióban alakulnak ki. (TAD = transzaktivációs domén; DBD = DNS-kötő domén; LZD = leucincipzár domén) 
melyek az N-terminális régióra lokalizálódó kis out-offrame deléciók/inzerciók vagy nonsense mutációk, amelyek korai STOP kodont eredményezve állítják le a fehérje szintézisét. Ennek következtében egy 30 kDa-os rövidebb forma is expresszálódik (p30), ami túlsúlyba kerülve domináns gátló hatással bír a $42 \mathrm{kDa}-\mathrm{os}$ vad típusú fehérje (p42) müködésére [6]. A másik csoportba a szomatikus/ szerzett mutációkat soroljuk, elsősorban a C-terminális régiót érintő nagyobb in-frame duplikációk/inzerciók a bZIP doménban, amelyek következtében a fehérje nem képes a DNS-hez kötődni, illetve a dimerizáció is gátolt (1. ábra) $[7,8]$.

A mutáció megjelenési formáját tekintve lehet monoallélikus („single”) CEBPA-mutáció, vagy biallélikus („double”) CEBPA-mutáció ( $C E B P A-\mathrm{dm})$. Monoallélikus mutációkról beszélünk, amikor csak az egyik allél (Nvagy C-terminális) érintett. Ezek prognosztikai jelentőséggel nem rendelkeznek [1]. Ezzel szemben a 2016-os akut leukémiákra vonatkozó WHO-klasszifikáció alapján a biallélikus $(C E B P A-\mathrm{dm})$ mutációk, amikor az $\mathrm{N}$ - és a $\mathrm{C}$ terminális egyaránt érintett, kedvező prognózissal járnak együtt [1].

\section{A CEBPA-mutáció laboratóriumi diagnosztikája}

Jelenleg erre a célra a legszélesebb körben alkalmazott laboratóriumi módszer a Sanger-féle bidirekcionális szekvenálás, melynek során a $C E B P A$-t kódoló gyakorlatilag teljes génszakaszt három primerpár segítségével „lefedve” tudjuk vizsgálni. Ugyanakkor a mutációk ily módon történő analízisét bizonyos metodikai körülmények limitálhatják, elsősorban a $C E B P A$ gén magas $\mathrm{GC}$ nukleotid tartalma, ami a polimeráz láncreakció (PCR) lezajlását meghiúsíthatja. Ennek elkerülése érdekében a PCR reakció ún. GC enhancer reagenst tartalmazó kittel optimalizálható [9].
A három fragmens elektroferogramjainak értékelése során az első fragmensben látott genetikai eltérések (általában deléciók/inzerciók) a N-terminálisban, a harmadik fragmensben bekövetkezett nukleotidsorrend változások (általában duplikációk/inzerciók) a C-terminálisban kialakult mutációkat igazolják. A második fragmensben látott mutációk besorolásában a különböző adatbázisok (pl. https://cancer.sanger.ac.uk/cosmic, www.mutationtaster.org stb.) nyújthatnak segítséget. Tekintettel arra, hogy egy rendkívül nagy heterogenitású génről van szó [10], a nagyszámban leírt mutációk mellett évről évre további új mutációk kerülnek felismerésre, különösen a C-terminálisban látott, egymástól akár csak 1-1 nukleotid eltérést mutató komplex genetikai változások. Olyan is előfordulhat, hogy egy korábban mutációnak leírt genetikai eltérés késóbb egy nem patogén természetes variánsnak bizonyul (pl. a 6 bázispáros duplikáció: c.584_589dupACCCGC, p.P196_P197insHP).

A jelentős hatással bíró mutációk mellett számos polimorfizmus is detektálható, melyek populációfüggő módon a betegek jelentős, akár 15-20\%-ában is jelen vannak, vagyis gyakrabban, mint maguk a $C E B P A$-mutációk [11]. Nagy részük nem okoz aminosavcserét, azért nem járnak a CEBPA fehérje megváltozott szerkezetével, és így klinikai jelentőségük nincsen [12]. A 2. táblázatban kerültek öszszefoglalásra két hazai diagnosztikai centrumban kimutatott leggyakoribb $C E B P A$-mutációk.

A Sanger-szekvenálás mellett a PCR-t követő kapilláris elektroforézis fragmenthossz analízis szintén alkalmas módszer az AML-es betegek vizsgálatára [13]. Ez a módszer akár $100 \%$-os specificitás és $93 \%$-os szenzitivitás mellett 1-5\%-os alsó detektálási határral a $C E B P A$-mutációk szürőmódszere lehet [13]. Bár a csúcsok magasságából a variáns allélfrekvencia megadható, ami előny a Sangerszekvenálással szemben, ugyanakkor nem tudja meghatározni a pontos lokalizációt. Az újgenerációs szekvenálás (NGS) fokozatos elterjedése viszont kiválthatja a Sanger-

2. táblázat. Két hazai diagnosztikai centrumban (Semmelweis Egyetem I. sz. Patológiai és Kísérleti Rákkutató Intézet; Debreceni Egyetem Laboratóriumi Medicina Intézet) eddigiekben kimutatott $C E B P A$-mutációk típusai. A zárójelben a nukleotid sorrendben, illetve a fehérjeszerkezetben bekövetkezett változás látható, helyenként kiegészítve az adott mutáció COSMIC adatbázisban szereplő azonosítószámával

\begin{tabular}{ll}
\hline N-terminális CEBPA-mutációk & C-terminális CEBPA-mutációk \\
\hline duplikáció (c.68dupC, p.H24fs, COSM18922) & inzerció (c.955_956ins45, p.T318_S319ins15). \\
duplikáció (c.230_237dupTCCTGGCC, p.D80fs) & komplex mutáció (c.690_701GCCCGTGCCCAG>T, p.V232fs) \\
duplikáció (c.57dupG, p.Q20fs) & inzerció (c.926_927insCCCCGG, p.E309_T310insPR) \\
deléció (c.181_187delTCCATCG, Ser61Thrfs*97) & inzerció (c.938_939insTCT, p.K313N, COSM32738) \\
deléció (c.184_191delATCGACAT, I62Qfs*43) & deléció (c.916_934delGCAACGTGGAGACGCAGC, p.R306fs) \\
inzerció (c.246_247insC, p.Q83fs) & deléció (c.695_705delTGCCCAGCCCG, p.V232fs) \\
deléció (c.134delA, p.P45fs) & deléció (c.611delC, p.P204fs, COSM29604) \\
deléció (c.135delA, p.P45fs) & deléció (c.917_936delins, p.R306fs) \\
inzerció (c.58_59insG, p.Q20fs) & duplikáció (c.926_928dup, p.K310fs) \\
inzerció (c.356_357insT, p.V119fs) & \\
inzerció (c.218_219insT, p.Q73fs) & \\
\hline
\end{tabular}


szekvenálást ezekben a genetikai vizsgálatokban is [14], mivel jóval nagyobb szenzitivitással bír (a szekvenálás mélységétől függően akár <1\% vs. 15-20\%). Egy myeloid génpanel keretén belül, bár a relapszus gyakorisága a $C E B P A$-mutáció vizsgálata akár több tucat egyéb AMLspecifikus gén egyidejü analízisével elvégezhető, ez még csak kevés helyen érhető el a rutin laboratóriumi diagnosztikában [15]. Bár jelenleg a három leggyakoribb AML prognosztikai marker (FLT3, NPM1, CEBPA) vizsgálata az „elvárt” a rutindiagnosztikai laboratóriumok többségében, a szélesebb mutációs génpanelek használata tovább segítheti a betegek prognosztikai besorolását [16]. Ezen túlmenően a teljes exomszekvenálás (WES) a betegség klonális evolúciójának feltérképezését is lehetővé teheti az örökletes AML-es kórképek/családok esetében [17] (lásd később).

\section{A CEBPA-mutációk klinikai jelentősége}

Az utóbbi évek klinikai vizsgálatai és az AML-re vonatkozó legújabb irányelvek alapján a $C E B P A$-mutációk jelenléte jelentősen befolyásolja az AML klinikai kimenetelét [18]. Több mint 200 fős AML-es populáció (medián életkor 48,5 [23-72] év) eredményei alapján a $C E B P A-d m$ betegek az első indukciós kezelés után nagyobb komplett remissziós arányt mutattak, mint a vad típusú személyek (87,5\% vs. 61,0\%) [19]. Ezen kedvező tendenciák akkor sem változtak, amikor a túlélési görbéket allogén csontvelö-transzplantációban részesült betegek körében is meghatározták [19]. A biallélikus CEBPA-mutációval rendelkező idősebb, legalább 60 éves betegek körében már szerényebb különbséget észleltek, de így is a komplett remisszió aránya magasabb $(75 \%)$ volt, mint azokban a személyekben, akikben vad típusú $C E B P A$ gént azonosítottak (59\%) [20]. A teljes túlélést jelentősen befolyásolta a kettős $C E B P A$-mutáció jelenléte a mutációt nem mutatókkal szemben (471 nap vs. 278 nap), de a 3 éves túlélésben jelentős különbség már nem volt mérhető a biallélikus $C E B P A$-mutációt mutató betegek javára (18\% vs. 17\%) [20]. A $C E B P A-\mathrm{dm}$ betegek külön is összehasonlításra kerültek a NPM1-mutációt és vad típusú FLT3-t mutató $\left(F L T 3^{W T}\right)$ személyekkel, valamint egy harmadik, egyéb betegcsoporttal („other genotypes”), amibe az összes többi beteget sorolták. Bár a relapszus gyakorisága az első év végén a NPM1-mutációt hordozó csoportban volt a legkisebb (NPM1 $1^{M U T}-F L T 3^{W T}$ vs. CEBPA-dm vs. „other genotypes”: $44 \%$, $56 \%$ és $62 \%$ ), ez a különbség három év után már $66 \%, 67 \%$ és $78 \%$ volt. A CEBPA-dm és $N P M 1^{M U T}$-FLT3 ${ }^{W T}$ csoportokban a betegség hasonló lefolyást mutatott, ezért ezt a két csoportot összevonták és mint egy „kedvező rizikójú” csoportot kezelték tovább. Összehasonlítva az egyéb csoporttal, a két csoport teljes túlélése (OS) jelentős különbséget mutatott: a hároméves OS: $27 \%$ vs. $12 \%$ volt. Összességében az AML prognosztikai faktorok genetikai eltéréseinek együttes kombinációja (CEBPA-dm, NPM1 mutáció és FLT3 $\left.{ }^{W T}\right)$ kedvezőbb prognózist biztosított, mint az egyéb genotípusok kombinációja ( $57 \%$ vs. 33\% az 1 éves túlélés esélye) [20].

A fiatalabb, 60 év alatti korcsoportot vizsgálva határozottabb volt a $C E B P A$-dm kedvező prognosztikai hatása, mivel a tízéves OS $81 \%$, a 10 éves relapszusmentes túlélés (RFS) 66\% volt [21]. Még fiatalabb felnőtt AML-es személyek körében (átlagéletkor a diagnóziskor 43 év) végzett tanulmány is megállapította, hogy a $C E B P A$-dm-betegeknek jobb (54\%) a nyolcéves túlélése, mint a vad típusú, vagy az egy $C E B P A$-mutációt mutató betegeké (34\% és $31 \%$ ) [22]. Gyermekkorban a normál kariotípusú AML-es betegekben is hasonló volt a $C E B P A$-mutációk gyakorisága (12\%), és a legjobb kimenetelt a $N P M 1^{M U T} / F L T 3^{W T}$ negatív személyek mutatták [23]. A monoallélikus $C E B P A$ pozitív személyek érdekes módon sokkal heterogénebb génexpressziós profilt mutattak és gyakrabban kialakult FLT3 ${ }^{I T D}$ mutáció társulást mutattak, mint a vad típusú, vagy akár a $C E B P A$-dm egyének [24].

Kiemelendő, hogy az FLT3 ${ }^{I T D}$ mutáció jelenléte akár a CEBPA-, akár a NPM1-mutációk kedvező prognózisát lerontja [25]. A biallélikus CEBPA-mutációt hordozó egyének mintegy 20\%-ában a sporadikus GATA2 gént érintő mutáció kedvezőbb prognózist eredményez, ugyanakkor az FLT3-mutációval együtt ritkán fordulnak elő [26]. Mások szerint a GATA2 gén státusz nem befolyásolta érdemben a $C E B P A$-dm és $F L T 3^{W T}$ betegek kedvezőbb életkilátásait [27].

$\mathrm{Az}$ allogén őssejt-transzplantáció megítélésekor a hagyományos rizikófaktorok (életkor, társbetegségek, obezitás stb.) mellett számos más tényezőt, pl. kezdeti nagy fehérvérsejtszám, az FLT3 ${ }^{I T D}$, NPM1, CEBPA gének mutációs státusza, perzisztáló reziduális leukémia, komplex kariotípus stb., is figyelembe kell venni, amik befolyásolják a betegség lefolyását, és az első remisszió utáni kezelési stratégia megválasztását (kemoterápia vagy allogén őssejt-transzplantáció). Egy közelmúltban publikált vizsgálat szerint azoknak a betegeknek, akik $F L T 3^{I T D}$-pozitívak voltak, az allogén őssejt-transzplantáció jelentősen javította az életkilátásait (52 vs. 32 hónap a 10 éves követés alatt) [28]. A CEBPA gén státusz vonatkozásában a monoallélikus $C E B P A$ vagy $C E B P A^{W T}$ személyekben szintén az allogén csontvelö-transzplantációnak volt kedvezőbb hatása, míg a $C E B P A-d m$ betegeknél a kemoterápia tünt a választandó beavatkozásnak [28]. Egyelőre kevés információ áll rendelkezésre a $C E B P A$-mutáció és a csontvelőtranszplantáció alkalmazhatóságának további összefüggéseiröl.

A $C E B P A$-génmutáció státusza meghatározza a különböző csontvelői sejtek immunfenotípus mintázatát is egy korábbi áramlási citometriai vizsgálat szerint [19]. A CEBPA-dm betegek csontvelői mintáiból „szortolt” myeloblastok magasabb CD34-, CD7-, és CD15-pozitivitást mutattak szemben az egy $C E B P A$-mutációra pozitív vagy a vad típusú személyek mintáival. $C E B P A-\mathrm{dm}$ jelenlétében a neutrophil granulocyták oldalra szórt fénytulajdonságai (SSC) csökkentek voltak, míg az erythroidok CD117- és a monocyták CD64-pozitivitása emelkedettebb 
volt, mint a másik két genetikai csoportban. Mindezen sejtfelszíni tulajdonságok tehát szoros összefüggésben állhatnak a betegségre jellemző genetikai eltérésekkel AMLben [19].

\section{Familiáris AML kialakulása „germline” CEBPA-mutációkkal}

Bár az AML döntően sporadikus megjelenésü, megfigyelhető a familiáris formája is, melynek hátterében a $C E B P A$ mutáció autoszomális domináns módon öröklődő mutációi állnak. A kórkép fiatalkorban, jellemzően 2-49 év között jelentkezik előzetes hematológiai megbetegedés, dysplasiás vagy pancytopéniás epizód nélkül. A "germline” CEBPA-mutációk közel $100 \%$-os penetranciával okoznak de novo AML-t, ami kedvezőbb kórlefolyást mutat. Nehéz megállapítani a valós prevalenciáját, ami feltehetően alábecsült a betegség változatos kialakulása és a családi anamnézisek hiánya miatt. A sporadikusnak tűnő $C E B P A-m u-$ tációk kb. 10\%-a utólagos vizsgálatok alapján valójában örökletesek [7]. A közelmúltban igazolták, hogy a familiáris AML progresszió egyes eseteiben nem ugyanazt a csírasejtes $C E B P A$-mutációt hordozó klón jelenik meg újra, hanem egy új, másik független klón válik detektálhatóvá. Így a visszatérő betegség igazából nem relapszus, hanem egy második de novo AML [17]. Tíz CEBPA-mutációra pozitív család WES alapú részletes kivizsgálása során kapott eredmények alapján a sporadikus monoallélikus $C E B P A$-mutációt hordozó AML több mutációt mutatott, mint a familiáris vagy sporadikus $C E B P A-\mathrm{dm}$ AML [17]. A GATA2- és a WT1-mutációk voltak a familiáris AML-ben látott leggyakoribb eltérések. Ezen túlmenően a monoallélikus $C E B P A$-mutáció jelenlétében a familiáris AML betegek kedvezőbb túlélési kilátásokat mutattak, mint a sporadikus esetek, míg a familiáris és sporadikus CEBPA-dm betegekben nem volt jelentős különbség. A relapszus bár sporadikus AML-ben hamarabb jelentkezett, szignifikánsan nem tért el a familiáris AML-től [17].

A familiáris MDS/AML kialakulásának hátterében számos autoszomális domináns módon öröklődő mutációk állnak, melyek alapján négy szindrómát különítünk meg: 1) a $C E B P A$-pozitív familiáris MDS/AML-t, 2) a GATA2-pozitív familiáris MDS/AML-t, 3) a familiáris vérlemezke-funkciózavar kapcsán kialakuló MDS/AML-t $R U N X 1$-pozitivitással, és 4) a csontvelő-kimerüléssel járó kórképek TERT és TERC génmutációval, illetve egyéb gének, mint a ANKRD26, ETV6, DDX41, SRP72 stb.) eltéréseivel [29, 30]. A fentiek tükrében bizonyos életkor alatt (pl. 40 év) érdemes lenne a CEBPA-mutáció csíravonalbeli eredetét tesztelni, mivel ezen öröklődő mutációkat hordozó esetek nagy részét hazánkban még nem ismerjük, a genetikai eltérések időbeni felismerése pedig biztosíthatja a vizsgált személy megfelelő nyomon követését, a csontvelő-transzplantáció egyéni elbírálását és a tünetmentes vérrokonok kiszürését [29, 30]. Amennyiben a
$C E B P A$-mutáció örökletesnek bizonyul, a beteg testvére nem lehet donor.

\section{Összefoglalás}

A fentiekben bemutatott leggyakoribb és ebből következőleg napjainkban a legszélesebb körben vizsgált AML-es genetikai eltérések, köztük a $C E B P A$ gén mutációinak analízise az elmúlt években hazánkban is a mindennapi rutindiagnosztika részévé vált, ami lehetővé teszi az AML-es betegek megfelelőbb egyéni állapotfelmérését, az MRD követését, a sporadikus és familiáris AML-es esetek elkülönítését, és az intenzív kemoterápia, valamint az őssejt-transzplantáció megítélését. Az NGS metodika és a mutációs génpanelek fokozatos elterjedésével egyre több genetikai eltérést lehet egyidejüleg megvizsgálni, segítve az adott malignus betegség hátterében álló bonyolult celluláris folyamatok, illetve a mutációk szerepének jobb megismerését. Ezért kell a széles körü vizsgálati profilt fokozatosan elérhetővé tenni minden nagy klinikai központban a korszerü laboratóriumi diagnosztika és a megfelelő terápiás beavatkozások biztosítása érdekében.

Nyilatkozat: A cikk nem jelent meg más folyóiratban és nem áll publikáció alatt. A szerzők a szerzői útmutatót elolvasták.

Anyagi támogatás: Ifj. Dr. Nagy Bélát a Szodoray Lajos Ösztöndíj (Debreceni Egyetem, ÁOK) támogatta. Dr. Gángó Ambrust az Új Nemzeti Kiválóság Program támogatta (ÚNKP-18-3-I-SE-48.).

Érdekeltségek: A szerzőknek nincsenek érdekeltségeik.

Szerzői munkamegosztás: Valamennyi szerző részt vett a közlemény megírásában, valamint az előzetes irodalmi adatok feldolgozásában.

\section{Irodalom}

[1] Arber DA, Orazi A, Hasserjian R, et al. The 2016 revision to the World Health Organization (WHO) classification of myeloid neoplasms and acute leukemia, Blood 2016; 127: 2391-2405.

[2] Döhner H, Estey E, Grimwade D, et al. Diagnosis and management of AML in adults: 2017 ELN recommendations from an international expert panel. Blood 2017; 129: 424-447.

[3] Grimwade D, Hills RK, Moorman AV, et al. National Cancer Research Institute Adult Leukaemia Working Group. Refinement of cytogenetic classification in acute myeloid leukemia: determination of prognostic significance of rare recurring chromosomal abnormalities among 5876 younger adult patients treated in the United Kingdom Medical Research Council trials. Blood 2010; 116: 354-365.

[4] Rajnai H, Király AP. Pathogenesis and genetic landscape of acute myeloid leukemia. [Az akut mieloid leukémia genetikai és patológiai sajátosságai.] Magy Onkol. 2017; 61: 21-28. [Hungarian]

[5] Avellino R, Delwel R. Expression and regulation of C/EBPa in normal myelopoiesis and in malignant transformation. Blood 2017; 129: 2083-2091. 
[6] Kato N, Kitaura J, Doki N, et al. Two types of C/EBPa mutations play distinct but collaborative roles in leukemogenesis: lessons from clinical data and BMT models. Blood 2011; 117: 221-233.

[7] Pabst T, Eyholzer M, Haefliger S, et al. Somatic CEBPA mutations are a frequent second event in families with germline $C E B P A \mathrm{mu}-$ tations and familial acute myeloid leukemia. J Clin Oncol. 2008; 26: 5088-5093

[8] Pabst T, Mueller BU. Complexity of CEBPA dysregulation in human acute myeloid leukemia. Clin Cancer Res. 2009; 15: 53035307.

[9] Burnett AK, Hills RK, Green C, et al. The impact on outcome of the addition of all-trans retinoic acid to intensive chemotherapy in younger patients with nonacute promyelocytic acute myeloid leukemia: overall results and results in genotypic subgroups defined by mutations in NPM1, FLT3, and CEBPA. Blood 2010; 115: 948956.

[10] Konstandin NP, Pastore F, Herold T, et al. Genetic heterogeneity of cytogenetically normal AML with mutations of $C E B P A$. Blood Adv. 2018; 2: 2724-2731.

[11] Leecharendkeat A, Tocharoentanaphol C, Auewarakul CU. CCAAT/enhancer binding protein-alpha polymorphisms occur more frequently than mutations in acute myeloid leukemia and exist across all cytogenetic risk groups and leukemia subtypes. Int J Cancer 2008; 123: 2321-2326.

[12] Sarojam S, Raveendran S, Vijay S, et al. Characterization of CEBPA Mutations and Polymorphisms and their Prognostic Relevance in De Novo Acute Myeloid Leukemia Patients. Asian Pac J Cancer Prev. 2015; 16: 3785-3792.

[13] Fuster O, Barragán E, Bolufer P, et al. Fragment length analysis screening for detection of $C E B P A$ mutations in intermediate-risk karyotype acute myeloid leukemia. Ann Hematol. 2012; 91: 1-7.

[14] Grossmann V, Schnittger S, Schindela S, et al. Strategy for robust detection of insertions, deletions, and point mutations in $C E B P A$, a GC-rich content gene, using 454 next-generation deep-sequencing technology. J Mol Diagn. 2011; 13: 129-136.

[15] Nardi V, Hasserjian RP. Genetic Testing in Acute Myeloid Leukemia and Myelodysplastic Syndromes. Surg Pathol Clin. 2016; 9 : 143-163.

[16] Thakral G, Vierkoetter K, Namiki S, et al. AML multi-gene panel testing: A review and comparison of two gene panels. Pathol Res Pract. 2016; 212: 372-380.

[17] Tawana K, Wang J, Renneville A, et al. Disease evolution and outcomes in familial AML with germline $C E B P A$ mutations. Blood 2015; 126: 1214-1223.

[18] Fey MF, Buske C. ESMO Guidelines Working Group. Acute myeloblastic leukaemias in adult patients: ESMO Clinical Practice Guidelines for diagnosis, treatment and follow-up. Ann Oncol. 2013; 24 Suppl 6: vi138-143.
[19] Mannelli F, Ponziani V, Bencini S, et al. CEBPA-double-mutated acute myeloid leukemia displays a unique phenotypic profile: a reliable screening method and insight into biological features. Haematologica 2017; 102: 529-540.

[20] Dickson GJ, Bustraan S, Hills RK, et al. The value of molecular stratification for CEBPA(DM) and NPM1(MUT) FLT3(WT) genotypes in older patients with acute myeloid leukaemia. $\mathrm{Br} \mathrm{J}$ Haematol. 2016; 172: 573-580.

[21] Pastore F, Kling D, Hoster E, et al. Long-term follow-up of cytogenetically normal CEBPA-mutated AML. J Hematol Oncol. 2014; 7: 55 .

[22] Green CL, Koo KK, Hills RK, et al. Prognostic significance of $C E B P A$ mutations in a large cohort of younger adult patients with acute myeloid leukemia: impact of double $C E B P A$ mutations and the interaction with FLT3 and NPM1 mutations. J Clin Oncol. 2010; 28: 2739-2747.

[23] Rubio P, Campos B, Digiorge JA, et al. NPM1, FLT3 and CEBPA mutations in pediatric patients with AML form Argentina: incidence and prognostic value. Int Hematol. 2016; 104: 582-590.

[24] Dufour A, Schneider F, Metzeler KH, et al. Acute myeloid leukemia with biallelic $C E B P A$ gene mutations and normal karyotype represents a distinct genetic entity associated with a favorable clinical outcome. J Clin Oncol. 2010; 28: 570-577.

[25] Port M, Böttcher M, Thol F, et al. Prognostic significance of FLT3 internal tandem duplication, nucleophosmin 1, and CEBPA gene mutations for acute myeloid leukemia patients with normal karyotype and younger than 60 years: a systematic review and metaanalysis. Ann Hematol. 2014; 93: 1279-1286.

[26] Fasan A, Eder C, Haferlach C, et al. GATA2 mutations are frequent in intermediate-risk karyotype AML with biallelic CEBPA mutations and are associated with favorable prognosis. Leukemia 2013; 27: 482-485.

[27] Green CL, Tawana K, Hills RK, et al. GATA2 mutations in sporadic and familial acute myeloid leukaemia patients with $C E B P A$ mutations. Br J Haematol. 2013; 161: 701-705.

[28] Kurosawa S, Yamaguchi H, Yamaguchi T, et al. Decision Analysis of Postremission Therapy in Cytogenetically Intermediate-Risk Acute Myeloid Leukemia: The Impact of FLT3 Internal Tandem Duplication, Nucleophosmin, and CCAAT/Enhancer Binding Protein Alpha. Biol Blood Marrow Transplant. 2016; 22: 11251132.

[29] Király AP, Kállay K, Marosvári D, et al. Clinical and genetic background of familial myelodysplasia and acute myeloid leukemia. [Familiáris myelodysplasiás szindróma és akut myeloid leukaemia klinikai és genetikai háttere.] Orv Hetil. 2016; 157: 283-289. [Hungarian]

[30] Király AP, Kállay K, Gángó A, et al. Familial Acute Myeloid Leukemia and Myelodysplasia in Hungary. Pathol Oncol Res. 2018; 24 : $83-88$.

A cikk a Creative Commons Attribution 4.0 International License (https://creativecommons.org/licenses/by/4.0/) feltételei szerint publikált Open Access közlemény, melynek szellemében a cikk bármilyen médiumban szabadon felhasználható, megosztható és újraközölhető, feltéve, hogy az eredeti szerző és a közlés helye, illetve a CC License linkje és az esetlegesen végrehajtott módosítások feltüntetésre kerülnek. (SID_1) 